\title{
Salmonella reference collection B (SARB): strains of 37 serovars of subspecies I
}

\author{
E. Fidelma Boyd, Fu-Sheng Wang, Pilar Beltran, Sheila A. Plock, Kimberlyn Nelson \\ and Robert K. SElander*
}

Institute of Molecular Evolutionary Genetics, Mueller Laboratory, Pennsylvania State University, University Park, Pennsylvania 16802, USA

(Received 1 September 1992; revised 23 December 1992; accepted 10 February 1993)

\begin{abstract}
A reference collection of 72 strains representing 37 serovars of Salmonella subspecies I has been established for use in research on genetic and phenotypic variation in natural populations. Included are isolates of the host-adapted serovars $S$. choleraesuis, $S$. dublin, $S$. gallinarum, S. paratyphi $A, S$. paratyphi B, S. paratyphi $C, S$. pullorum, $S$. sendai, $S$. typhi and $S$. typhisuis, as well as strains of $S$. enteritidis, $S$. typhimurium, and other commonly recovered serovars with broad host ranges. The isolates were characterized by enzyme electrophoresis for allelic variation in 25 chromosomal genes and represent 71 distinctive multilocus genotypes (electrophoretic types or ETs). Genetic relationships among the ETs are indicated in an evolutionary tree constructed by the neighbourjoining method from a matrix of Nei's standard genetic distance.
\end{abstract}

\section{Introduction}

Among bacteria of the genus Salmonella, eight subgroups have been distinguished on the basis of hybridization of genomic DNA (Crosa et al., 1973; Le Minor et al., 1986), multilocus enzyme electrophoresis (MLEE) (Reeves et al., 1989; Selander et al., 1991), biotyping (Ewing, 1986; Le Minor et al., 1986), and, most recently, nucleotide sequence analysis of chromosomal genes (Nelson et al., 1991; Nelson \& Selander, 1992). These groups are generally regarded as subspecies of a single species, designated as $S$. enterica (Le Minor \& Popoff, 1987), but it has recently been proposed that the strains of group $\mathrm{V}$ are sufficiently differentiated from those of the other groups to warrant recognition as a distinct species, $S$. bongori (Reeves et al., 1989).

Within the subspecies, strains are conventionally identified and classified according to the KauffmannWhite serotyping scheme, which is based on antigenic variation in the outer-membrane lipopolysaccharide (O) and phase $1(\mathrm{H} 1)$ and phase 2 (H2) flagella (Le Minor 1984, 1988; Ewing, 1986). Of the 2200

*Author for correspondence. Tel. (814) 865 2002; fax (814) 8634706.

Abbreviations: ET, electrophoretic type; MLEE, multilocus enzyme electrophoresis; SARA, Salmonella reference collection A; SARB, Salmonella reference collection B. serovars that have been distinguished, $99 \%$, including all the major human pathogenic types, are members of subspecies I. Historically, serovars were designated by Latin binomials (e.g. Salmonella typhimurium), as if they were distinct species. This nomenclature is still widely used, although taxonomic schemes have recently been proposed in which the serovar names are used vernacularly (e.g. $S$. enterica serovar Typhimurium) (Ewing, 1986).

Serotyping is a convenient and epidemiologically useful method of categorizing isolates, but it does not provide a basis for estimating evolutionary genetic relatedness among strains. Studies of electrophoretically demonstrable allelic variation at multiple enzyme loci have recently demonstrated that isolates of the same serovar may be distantly related in chromosomal genotype, and that, conversely, strains of different serovars may be virtually identical in overall genetic character (Beltran et al., 1988; Selander et al., 1990 b). For the phase I flagellin gene $(\mathrm{fliC})$, comparative sequence analysis of multiple strains of Salmonella for which MLEE has provided an evolutionary framework has strongly implicated horizontal genetic transfer and substitutive recombination as a major process generating new serovars (Smith \& Selander, 1990, 1991; Smith et al., 1990). And there is evidence that gene transfer and recombination have also been extensively involved in the diversification of the $r f b$ gene cluster mediating serotypic 
Table 1. Properties of the 72 strains of the Salmonella reference collection B (SARB), representing 37 serovars of subspecies $I$

\begin{tabular}{|c|c|c|c|c|c|c|c|}
\hline $\begin{array}{c}\text { SARB } \\
\text { no. }\end{array}$ & $\begin{array}{l}\text { RKS } \\
\text { no. }\end{array}$ & ET & $\begin{array}{l}\text { Original } \\
\text { number* }\end{array}$ & Source & Locality & Biotype $\uparrow$ & Date \\
\hline \multicolumn{8}{|c|}{ Salmonella agona $(1,4,12: \mathrm{f}, \mathrm{g}, \mathrm{s}:--) \ddagger$} \\
\hline 1 & 1701 & $\mathrm{Ag} 1$ & IVB $36 / 79$ & - & Peru & - & - \\
\hline \multicolumn{8}{|c|}{ Salmonella anatum $(3,10: \mathrm{e}, \mathrm{h}: 1,6)$} \\
\hline 2 & 2403 & An 1 & CDC B1487 & Human & Washington & - & - \\
\hline \multicolumn{8}{|c|}{ Salmonella brandenburg $\left(1,4,12: 1, \mathrm{v}: \mathrm{e}, \mathrm{n}, \mathrm{z}_{15}\right)$} \\
\hline 3 & 4231 & $\mathrm{Ba} 2$ & DMS 2819 & - & Scotland & $10 \mathrm{i}$ & 1988 \\
\hline \multicolumn{8}{|c|}{ Salmonella choleraesuis $(6,7:[c]: 1,5)$} \\
\hline 4 & 1280 & Cs 1 & NVSL 6321 & Swine & Minnesota & - & 1986 \\
\hline 5 & 1239 & Cs 6 & IVB $651 / 79$ & - & Switzerland & - & - \\
\hline 6 & 3169 & Cs 11 & CDC $3327 / 54$ & - & Thailand & & 1954 \\
\hline 7 & 4640 & Cs 13 & IP $6562 / 88$ & - & Australia & - & - \\
\hline \multicolumn{8}{|c|}{ Salmonella decatur $(6,7: \mathrm{c}: 1,5) \S$} \\
\hline 8 & 4647 & $\mathrm{Dt} 1$ & IP $631 \mathrm{~K}$ & - & France & - & - \\
\hline \multicolumn{8}{|c|}{ Salmonella derby $(1,4,[5], 12: \mathrm{f}, \mathrm{g}:[1,2])$} \\
\hline 9 & 246 & De 1 & NVSL 4111 & Avian & Oklahoma & - & 1986 \\
\hline 10 & 241 & De 13 & NVSL 5558 & Swine & Minnesota & - & 1986 \\
\hline 11 & 243 & De 31 & NVSL 5283 & Turkey & Pennsylvania & - & 1986 \\
\hline \multicolumn{8}{|c|}{ Salmonella dublin $(1,9,12,[\mathrm{Vi}]: \mathrm{g}, \mathrm{p}:--)$} \\
\hline 12 & $15 \overline{18}$ & Du 1 & NVSL 5618 & Cattle & Idaho & - & 1986 \\
\hline 13 & 4717 & Du 3 & IP $82 / 3144$ & Bovine & France & -- & 1982 \\
\hline 14 & 1550 & Du $2 \|$ & IVB $3540 / 24$ & - & Thailand & - & - \\
\hline \multicolumn{8}{|c|}{ Salmonella duisburg $\left(1,4,12,27: \mathrm{d}: \mathrm{e}, \mathrm{n}, \mathrm{z}_{15}\right)$} \\
\hline 15 & 4239 & $\overline{\mathrm{D}} \mathrm{i} 1$ & DMS 3618 & - & Scotland & $9 \mathrm{i}$ & 1988 \\
\hline \multicolumn{8}{|c|}{ Salmonella enteritidis $(1,9,12: \mathrm{g}, \mathrm{m}:[1,7])$} \\
\hline 16 & 53 & En 1 & CDC SSU7998 & - & Rhode Island & - & - \\
\hline 17 & 761 & En 2 & IVB $176 / 82$ & - & Brazil & - & - \\
\hline 18 & 69 & En 3 & CDC SSU8074 & - & Connecticut & - & - \\
\hline 19 & 1208 & En 7 & IVB $470 / 82$ & - & Switzerland & - & - \\
\hline \multicolumn{8}{|c|}{ Salmonella emek $(8, \underline{20}: \mathrm{g}, \mathrm{m}, \mathrm{s}:--)$} \\
\hline 20 & 1216 & Em 1 & IVB $4793 / 3366$ & - & Israel & - & - \\
\hline \multicolumn{8}{|c|}{ Salmonella gallinarum $(1,9,12:--:--) \uparrow$} \\
\hline 21 & 2962 & $\mathrm{Ga} 2$ & $\mathrm{CDC} 4801 / 72$ & Human & Connecticut & - & 1972 \\
\hline \multicolumn{8}{|c|}{ Salmonella haifa $\left(1,4,[5], 12: \mathrm{z}_{10}: 1,2\right)$} \\
\hline 22 & 4241 & Ha 1 & DMS 3005 & - & Scotland & $1 \mathrm{a}$ & 1988 \\
\hline \multicolumn{8}{|c|}{ Salmonella heidelberg $(1,4,[5], 12: r: 1,2)$} \\
\hline 23 & 539 & He 1 & NVSL 7039 & Chicken & Pennsylvania & $9 \mathrm{i}$ & 1987 \\
\hline 24 & 1391 & He 3 & IVB $588 / 24$ & - & Thailand & $1 \mathrm{a}$ & - \\
\hline Salmone & iana $(1$, & $\mathrm{z}: 1,7)$ & & & & & \\
\hline 25 & 4250 & Id 1 & DMS 3702 & - & Scotland & $1 \mathrm{a}$ & 1988 \\
\hline Salmone & antis $(6$, & 1,5) & & & & & \\
\hline 26 & 1490 & In 1 & CDC B 3460 & Human & North Carolina & - & - \\
\hline 27 & 1452 & In 3 & IVB $385 / 72$ & - & Senegal & - & - \\
\hline Salmone & $m i(1,9$ & $: 1,5)$ & & & & & \\
\hline 28 & 2833 & Mi 1 & CDC $4648 / 53$ & Human & Georgia & - & 1953 \\
\hline 29 & 4381 & Mi 5 & IP $2 / 79$ & Human & French Guiana & - & 1979 \\
\hline Salmone & ntevideo & $: \mathrm{g}, \mathrm{m},[\mathrm{p}]$, & & & & & \\
\hline 30 & 1762 & Mo 1 & CDC B2131 & Human & Georgia & - & - \\
\hline 31 & 1740 & Mo 6 & CDC B2604 & Human & Florida & - & - \\
\hline Salmone & enchen & d:1,2) & & & & & \\
\hline 32 & 3121 & Mu 1 & ATCC 8388 & _- & Laboratory strain & - & - \\
\hline 33 & 4288 & Mu 2 & IP $11 / 88$ & Human & France & - & 1988 \\
\hline 34 & 4300 & Mu 3 & IP $25 / 88$ & Human & France & - & 1988 \\
\hline 35 & 4272 & Mu 4 & CDC B1293 & Human & North Carolina & - & - \\
\hline Salmone & pport $(6$ & $h: 1,2)$ & & & & & \\
\hline 36 & 2016 & Np 8 & CDC B3465 & Human & North Carolina & - & - \\
\hline 37 & 1915 & $\mathrm{~Np} 11$ & INSP 15 & Human & Mexico & - & - \\
\hline 38 & 1956 & Np 15 & NVSL 3882 & Snake & Massachusetts & - & 1987 \\
\hline Salmone & ama $(1$, & $: 1, \mathrm{v}: 1,5)$ & & & & & \\
\hline 39 & $1793^{-}$ & Pn 1 & IVB Bendia & - & Italy & - & - \\
\hline 40 & 1776 & Pn 2 & CDC B1171 & Human & North Carolina & - & - \\
\hline 41 & 1779 & Pn 12 & CDC B 1433 & Human & North Carolina & - & - \\
\hline Salmone & atyphi & $2,12: a:[$ & & & & & \\
\hline 42 & 4993 & $\mathrm{~Pa} 1$ & ATCC 9150 & _- & Laboratory strain & - & - \\
\hline
\end{tabular}


Table 1. (cont.)

\begin{tabular}{|c|c|c|c|c|c|c|c|}
\hline $\begin{array}{c}\text { SARB } \\
\text { no. }\end{array}$ & $\begin{array}{c}\text { RKS } \\
\text { no. }\end{array}$ & ET & $\begin{array}{l}\text { Original } \\
\text { number* }\end{array}$ & Source & Locality & Biotype $\dagger$ & Date \\
\hline \multicolumn{8}{|c|}{ Salmonella paratyphi $B$ (including variety java) $(1,4,[5], 12: \mathrm{b}:[1,2])$} \\
\hline 43 & 3222 & $\mathrm{~Pb} 1$ & DMS $155 / 76$ & Human & France & $3 \mathrm{gh}$ & 1976 \\
\hline 44 & 3202 & $\mathrm{~Pb} 3$ & DMS $106 / 76$ & Food & Middle East & $2 \mathrm{a}$ & 1976 \\
\hline 45 & 3201 & $\mathrm{~Pb} 4$ & DMS $83 / 76$ & Human & France & $13 \mathrm{i}$ & 1976 \\
\hline 46 & 3274 & $\mathrm{~Pb} 5$ & DMS 2471 & Water & United Kingdom & $11 \mathrm{i}$ & $<1965$ \\
\hline 47 & 3215 & $\mathrm{~Pb} 7$ & DMS $53 / 81$ & Human & Africa & $1 \mathrm{~g}$ & 1981 \\
\hline \multicolumn{8}{|c|}{ Salmonella paratyphi $C(6,7[\mathrm{Vi}]: \mathrm{c}: 1,5)$} \\
\hline 48 & 4587 & Pc 1 & IP $33 \mathrm{~K}$ & - & France & - & - \\
\hline 49 & 4594 & Pc 2 & IP $2 / 88$ & Human & France & - & 1988 \\
\hline 50 & 4620 & Pc 4 & IP $4 / 77$ & Human & France & - & 1977 \\
\hline \multicolumn{8}{|c|}{ Salmonella pullorum $(1,9,12:--:--) \#$} \\
\hline 51 & 2266 & Pu 3 & IVB $978 / 87$ & - & Germany & - & - \\
\hline 52 & 2246 & $\mathrm{Pu} 4$ & $\begin{array}{l}\text { IVB Italian } \\
\text { Standard }\end{array}$ & - & Germany & - & - \\
\hline \multicolumn{8}{|c|}{ Salmonella reading $(1,4,[5], 12: \mathrm{e}, \mathrm{h}: 1,5)$} \\
\hline 53 & 4256 & $\operatorname{Re} 1$ & DMS 3853 & - & Scotland & $2 \mathrm{j}$ & 1988 \\
\hline \multicolumn{8}{|c|}{ Salmonella rubislaw $(\mathrm{I} 1: \mathrm{r}: \mathrm{e}, \mathrm{n}, \mathrm{x})$} \\
\hline 54 & 4938 & Ru 1 & ATCC 10717 & - & Laboratory strain & - & - \\
\hline \multicolumn{8}{|c|}{ Salmonella saintpaul $(1,4,[5], 12: \mathrm{e}, \mathrm{h}: 1,2)$} \\
\hline 55 & 1690 & $\mathrm{Sp} 3$ & CDC B2076 & Human & Texas & - & - \\
\hline 56 & 1686 & $\mathrm{Sp} 4$ & CDC B 1400 & Human & Florida & - & - \\
\hline \multicolumn{8}{|c|}{ Salmonella schwarzengrund $(1,4,12, \underline{27}: \mathrm{d}: 1,7)$} \\
\hline 57 & $4261^{\circ}$ & Sw 1 & DMS 1253 & - & Scotland & $10 \mathrm{i}$ & 1988 \\
\hline \multicolumn{8}{|c|}{ Salmonella sendai $(1,9,12: \mathrm{a}: 1,5)$} \\
\hline 58 & 2866 & Se 1 & $\mathrm{CDC} 1035 / 74$ & Human & California & - & 1974 \\
\hline \multicolumn{8}{|c|}{ Salmonella senftenberg $(1,3,19: \mathrm{g},[\mathrm{s}], \mathrm{t}:--)$} \\
\hline 59 & $2358^{\circ}$ & Sf 1 & NVSL 6673 & Chicken & Maryland & - & 1987 \\
\hline \multicolumn{8}{|c|}{ Salmonella stanley $(1,4,[5], 12, \underline{27}: \mathrm{d}: 1,2)$} \\
\hline 60 & 4264 & St 1 & DMS 1112 & - & Scotland & 26 bei & 1988 \\
\hline \multicolumn{8}{|c|}{ Salmonella stanleyville $\left(1,4,[5], 12, \underline{27}: \mathrm{z}_{4}, \mathrm{z}_{23}:[1,2]\right)$} \\
\hline 61 & 4267 & Sv 2 & DMS 3705 & - & Scotland & $9 \mathrm{i}$ & 1988 \\
\hline \multicolumn{8}{|c|}{ Salmonella thompson $(6,7: \mathrm{k}: 1,5)$} \\
\hline 62 & 1767 & Th 1 & CDC B2637 & Human & Florida & - & - \\
\hline \multicolumn{8}{|c|}{ Salmonella typhi $\left(9,12,[\mathrm{Vi}]: \mathrm{d}:\left[\mathrm{Z}_{66}\right]\right)$} \\
\hline 63 & 3333 & Tp 1 & IP E. 88.374 & - & Dakar & - & 1988 \\
\hline 64 & 3320 & Tp 2 & IP E. 88.353 & - & Dakar & - & 1988 \\
\hline \multicolumn{8}{|c|}{ Salmonella typhimurium $(1,4,[5], 12: \mathrm{i}: 1,2)$} \\
\hline 65 & 284 & $\mathrm{Tm} 1$ & INSP 24 & Human & Mexico & $1 \mathrm{f}$ & - \\
\hline 66 & 203 & $\operatorname{Tm} 7$ & NVSL 2816 & Parrot & California & $1 \mathrm{a}$ & 1987 \\
\hline 67 & 837 & $\operatorname{Tm} 12$ & IVB 1430 & - & France & $29 \mathrm{~b}$ & - \\
\hline 68 & 4535 & $\operatorname{Tm} 23$ & USFW 318 & Heron & Oregon & - & - \\
\hline \multicolumn{8}{|c|}{ Salmonella typhisuis $(6,7: \mathrm{c}: 1,5)$} \\
\hline 69 & 3134 & Ts 1 & CDC $277 / 68$ & Swine & California & - & 1968 \\
\hline 70 & 3133 & Ts 3 & CDC $1426 / 67$ & Swine & Iowa & - & 1967 \\
\hline \multicolumn{8}{|c|}{ Salmonella wien $(1,4,12,27: \mathrm{b}: 1, \mathrm{w})$} \\
\hline 71 & 4000 & Wi 1 & IP $5 / 88$ & Human & France & - & 1988 \\
\hline 72 & 3998 & Wi 2 & IP $3 / 88$ & Human & France & - & 1988 \\
\hline
\end{tabular}

* Abbreviations: ATCC, American Type Culture Collection; CDC, Centers for Disease Control (Atlanta, Georgia); DMS, University of Dundee Medical School (Ruth Barker collection) (Dundee, Scotland); INSP, Instituto Nacional de Salud Publica (Cuernavaca, Mexico); IP, Institut Pasteur (Paris, France); IVB, Institut für Veterinarmedizin des Bundesgesundheitsamtes (Berlin, FRG); NVSL, National Veterinary Services Laboratories (Ames, Iowa); USFW, United States Fish and Wildlife collection (Ruth Duncan collection) (Madison, Wisconsin).

$\dagger$ Biotypes determined by D. C. Old (personal communication). For explanation of biotype designations, see Duguid et al. (1975) and Barker et al. (1988).

$\ddagger$ The serotype formula, indicating the $\mathrm{O}: \mathrm{H} 1: \mathrm{H} 2$ antigenic factors, is shown in parentheses for each serovar. See Le Minor (1984) for detailed explanation.

$\S$ Listed as a synonym of $S$. choleraesuis by Le Minor (1984).

|| Serotype 1,9,12:g,m,p:-- This strain has been serotyped as $S$. dublin but is distantly related to other strains of that serovar (see Selander et al., 1992).

ๆ Listed as $S$. gallinarum-pullorum by Le Minor (1984).

\# Listed as $S$. gallinarum-pullorum by Le Minor (1984) and as bioserovar Pullorum by Ewing (1986).

polymorphism in the somatic lipopolysaccharide of Salmonella (Brown et al., 1992; Lee et al., 1992; Wang et al., 1992).
Because of increasing interest on the part of microbiologists and molecular biologists in analysing genetic and phenotypic variation in natural populations of 


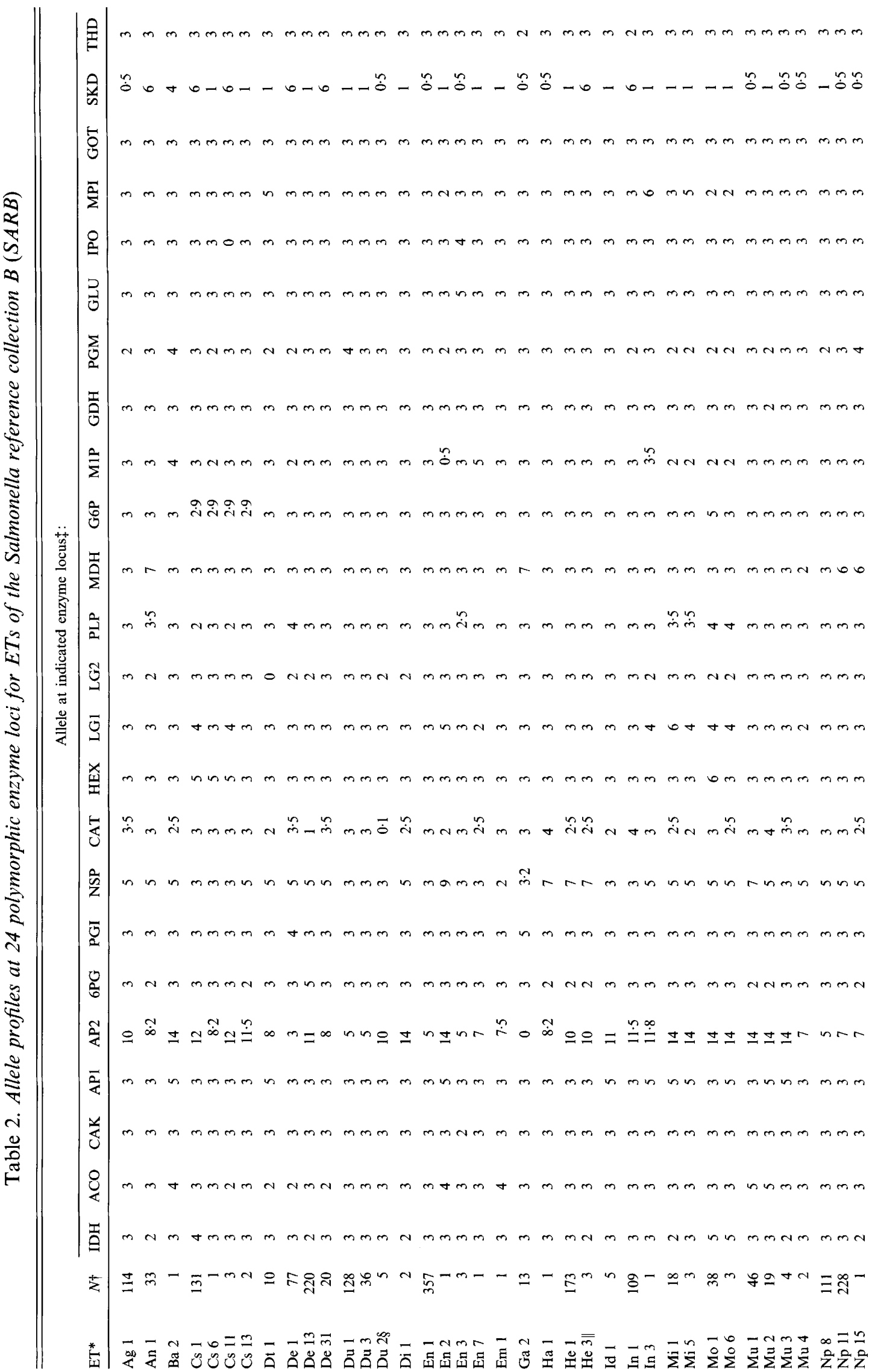




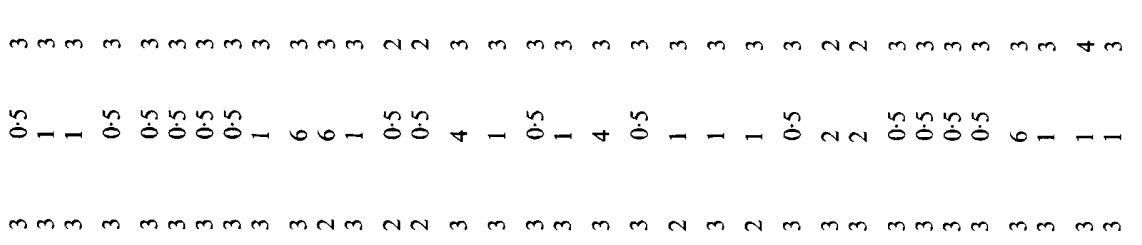

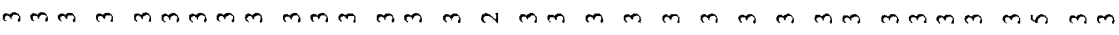

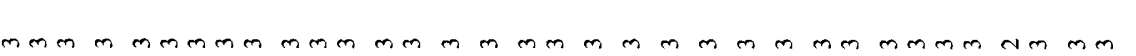

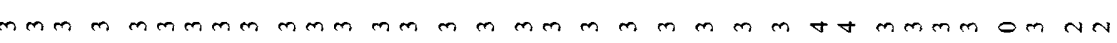

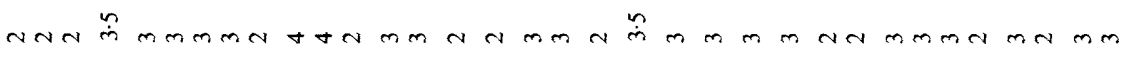

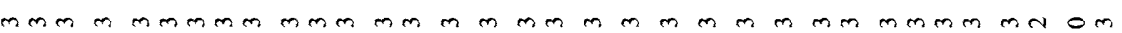

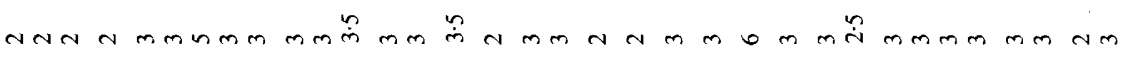
MmN

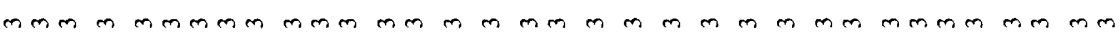

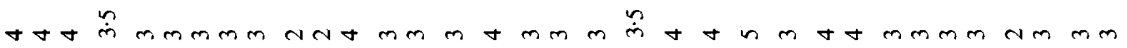

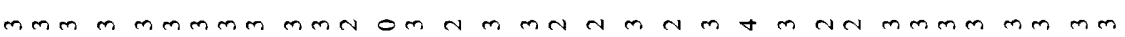

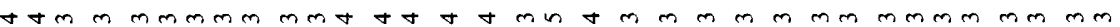
nmm m mmmmmmm mm m mmm mm m m $\ddot{\sim} \ddot{\sim} \ddot{i}$ o mnN

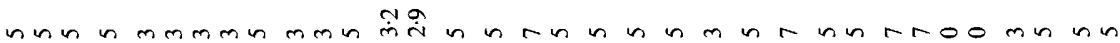

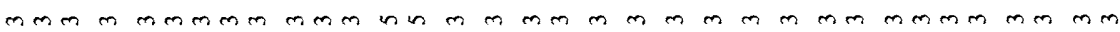

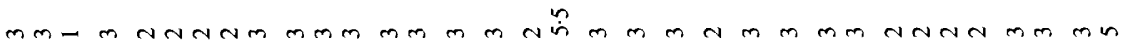

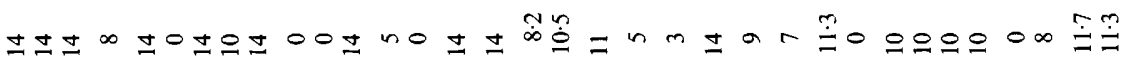
nun n mminmmmm o o n n min o m m mo num mmmmonmm

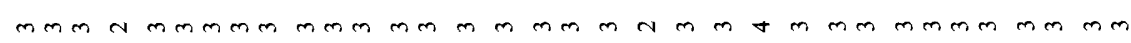

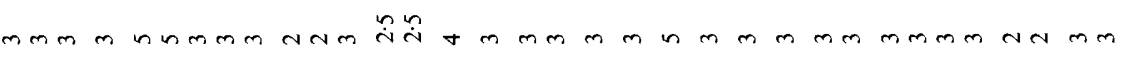
mma mammm mmm mm n m ma m m N N

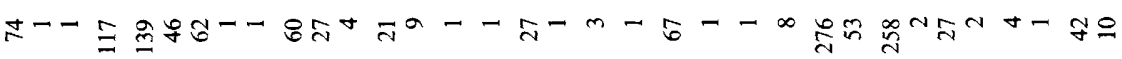

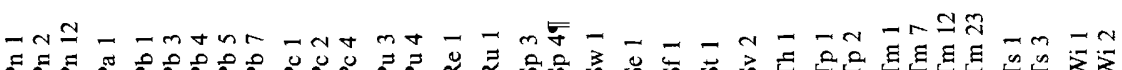

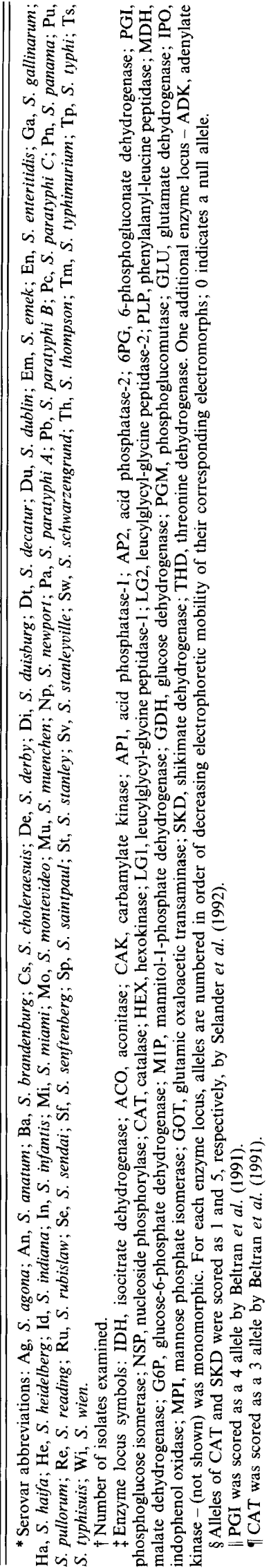




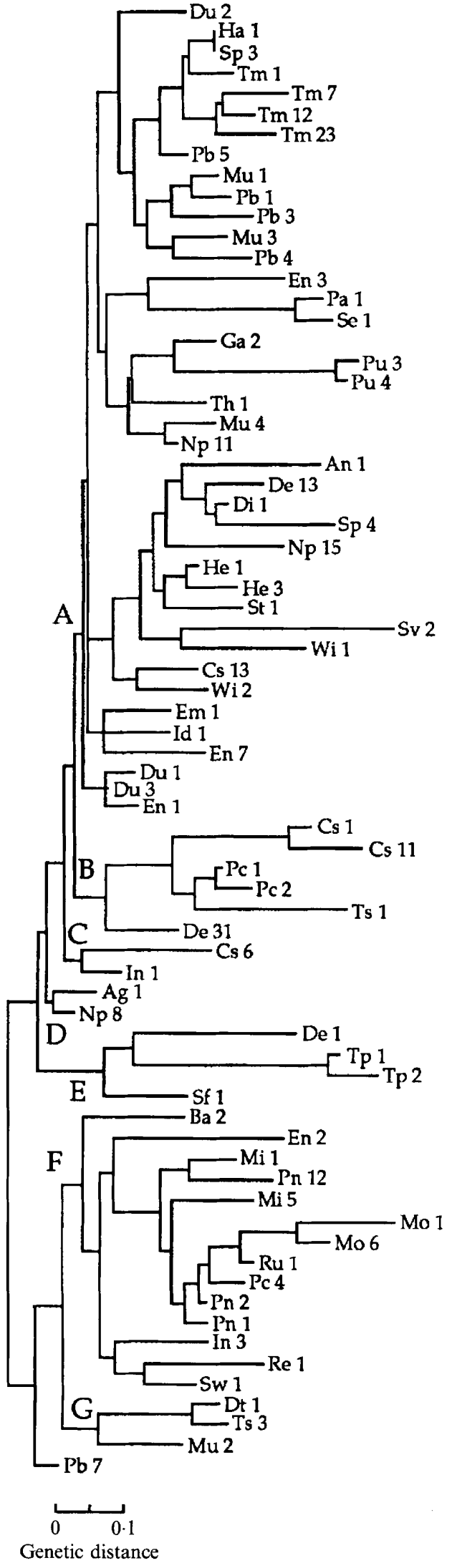

Salmonella, we have prepared several research reference collections of strains. Beltran et al. (1991) designated a set of 72 strains of the $S$. typhimurium complex (including representatives of the serovars $S$. typhimurium, $S$. saintpaul, $S$. heidelberg, $S$. paratyphi $B$ and $S$. muenchen) as the Salmonella reference collection A (SARA). We here report the availability of the Salmonella reference collection B (SARB), which consists of 72 strains representing 37 serovars of subspecies I, including the medically important human pathogenic forms.

\section{Methods}

Bacterial strains. In selecting the SARB strains (Table 1) from a collection of several thousand isolates that have been characterized in our laboratory by MLEE, we attempted to maximize representation of the genomic diversity within subspecies I. The strains are of 37 serovars; and for each of 19 serovars for which preliminary MLEE analyses had identified multiple electrophoretic types (ETs), we selected one isolate of the most frequently recovered ET and single isolates of one or more other ETs in order to reflect the total span of multilocus enzyme diversity among strains of the serovar. A total of 12 strains in SARB are also included in SARA.

$M L E E$. Electrophoretically demonstrable allelic variation in 25 chromosomal genes encoding metabolic enzymes was analysed by the methods described by Selander et al. (1986). Each isolate was grown overnight in $150 \mathrm{ml}$ brain heart infusion broth (Difco) at $37^{\circ} \mathrm{C}$ on an orbital shaker ( 250 r.p.m.) and harvested by centrifugation at $6000 \mathrm{~g}$ for $10 \mathrm{~min}$ at $4{ }^{\circ} \mathrm{C}$. Pelleted cells were resuspended in $2 \mathrm{ml} 50 \mathrm{~mm}-$ EDTA ( $\mathrm{pH} 7.5$ ); the bacteria were sonicated with a Sonifier Cell Disruptor (Branson Sonic Power Co.) with a microtip for $30 \mathrm{~s}$ at $50 \%$ pulse, with ice-water cooling; and a lysate was obtained by centrifugation at $20000 \mathrm{~g}$ for $20 \mathrm{~min}$ at $4^{\circ} \mathrm{C}$.

Lysates were electrophoresed on starch gels and selectively stained for 25 enzymes. Electromorph variants of an enzyme, numbered in order of decreasing anodal mobility, were equated with alleles at the corresponding structural gene locus. An absence of enzyme activity was attributed to a null allele (Selander et al., 1986), and all such null scores were verified by regrowing the strains and electrophoresing freshly prepared lysates. The enzymes studied and the allele profiles (multilocus enzyme genotypes) of the 72 SARB strains are shown in Table 2.

Statistical analysis. Statistical analyses were carried out by computer programs written by T.S. Whittam, Institute of Molecular Evolutionary Genetics. Estimates of genetic relationships among the ETs are indicated in the evolutionary tree in Fig. 1, which was generated by the neighbour-joining method (Saitou \& Nei, 1987) from a pairwise

Fig. 1. Evolutionary tree showing relationships among the 71 ETs represented by the 72 SARB strains. See text for explanation. Abbreviations of serovars: $\mathrm{Ag}, S$. agona; An, $S$. anatum; Ba, $S$. brandenburg; Cs, S. choleraesuis; De, $S$. derby; Di, $S$. duisburg; Dt, $S$. decatur; Du, S. dublin; Em, S. emek; En, S. enteritidis; Ga, S. gallinarum; Ha, $S$. haifa; He, $S$. heidelberg; Id, $S$. indiana; In, $S$. infantis; Mi, S. miami; Mo, S. montevideo; Mu, S. muenchen; $\mathrm{Np}$, $S$. newport $; \mathrm{Pa}, S$. paratyphi $A ; \mathrm{Pb}, S$. paratyphi $B ; \mathrm{Pc}, S$. paratyphi $C$; $\mathrm{Pn}, S$. panama; $\mathrm{Pu}, S$. pullorum; $\mathrm{Re}, S$. reading; $\mathrm{Ru}, S$. rubislaw; $\mathrm{Se}$, $S$. sendai; Sf, S. senftenberg; Sp, S. saintpaul; St, S. stanley; Sv, $S$. stanleyville; $\mathrm{Sw}, S$. schwarzengrund; Th, S. thompson; Tm, S. typhimurium; Tp, S. typhi; Ts, S. typhisuis; and Wi, S. wien. 
matrix of Nei's standard genetic distance (Nei, 1987) for the 25 enzyme loci assayed. Distance was calculated as $d_{i j}=-\ln (1-D)$, where $D$ equals the proportion of loci with different alleles between the $i$ th and $j$ th ETs. Under the assumptions that any allelic difference in electrophoretic mobility results from at least one codon difference at the nucleotide level and that codon changes occur independently, $d$ estimates the mean number of electrophoretically detectable codon differences per genetic locus (Nei, 1987; Herzer et al., 1990).

As drawn in Fig. 1, the tree is unrooted, but clustering of the SARB ETs with ETs of the other seven Salmonella subspecies as outgroups (data and analysis not shown) placed the root on the line leading to the two ETs of $S$. typhi (Tp 1 and Tp 2), in cluster E. For convenience of reference, seven divisions of the tree are designated by letter.

\section{Results and Discussion}

MLEE analysis of the 72 SARB isolates (Table 1) identified 71 distinctive ETs (Table 2). Isolate RKS 4241 (SARB 22), representing $S$. haifa (ET $\mathrm{Ha} \mathrm{1),} \mathrm{was}$ indistinguishable in allele profile from isolate RKS 1690 (SARB 55), representing Sp 3 of S. saintpaul.

Previous studies have shown that the population structure of Salmonella is clonal, with each serovar being represented by one or a few predominant clones of widespread if not global distribution (Beltran et al., 1988; Reeves et al., 1989; Selander et al., 1990a,b, 1992). Of the 19 serovars that are represented in SARB by two or more ETs, eight ( $S$. heidelberg, S. miami, $S$. montevideo, S. panama, S. pullorum, S. typhi, S. typhimurium and $S$. wien) are apparently monophyletic; the ETs of each of these serovars are genotypically similar and presumably have been derived through mutational divergence from a recent common ancestor. But the other 11 serovars $(S$. choleraesuis, $S$. derby, S. dublin, $S$. enteritidis, $S$. infantis, $S$. muenchen, $S$. newport, $S$. paratyphi $B, S$. paratyphi $C, S$. saintpaul and $S$. typhisuis) are each polyphyletic, as previously noted (Beltran $e t$ al., 1988, 1991; Selander et al., 1990a,b, 1992; Li et al., 1993), with, in most cases, ETs occurring in two or more divisions of the evolutionary tree (Fig. 1).

Genetic variation and evolutionary relationship within and among several of the serovars included in SARB have previously been studied in detail. In an analysis of multilocus enzyme genotypes and sequence variation in the $\mathrm{fiC}$ gene, the flagellar hook-associated protein 1 gene $(f g K)$, and the 6-phosphogluconate dehydrogenase gene (gnd), Li et al. (1993) concluded that strains of the nonmotile avian-adapted biovars $S$. gallinarum and $S$. pullorum shared a most recent common ancestor and are phylogenetically related to the common clonal lineage, En 1, of S. enteritidis. In the present analysis (Fig. 1), $\mathrm{Ga} 2$ clusters with Pu 3 and Pu 4 and occurs with En 1, En 3 and En 7 in division A. But $S$. enteritidis is a polyphyletic serovar (Beltran et al., 1988), and En 2 (in division F) is distantly related to other ETs of that serovar, except in the sequence of its $\mathrm{AlC}$ gene, which was apparently acquired by horizontal transfer ( $\mathrm{Li}$ et al., 1993).

A close relationship between ETs Du 1 and Du 3 of $S$. dublin and En 1 and similar ETs of S. enteritidis, as shown by Selander et al. (1992), is indicated in Fig. 1 (division A). Du 2 also occurs in division A but clusters with the main group of $S$. typhimurium and $S$. paratyphi $B$ ETs. Similarly, most of the ETs of $S$. paratyphi $B$ are allied with those of $S$. typhimurium (division $\mathrm{A}$ ), but $\mathrm{Pb} 7$ (at the bottom of the tree) is only distantly related to the other ETs of $S$. paratyphi B (Selander et al., 1990a; Beltran et al., 1991).

The three ETs of $S$. derby included in SARB differ from each other, on average, at nine enzyme loci and occur in three divisions (A, B and E) of the evolutionary tree (Fig. 1), reflecting multiple evolutionary origins (Beltran et al., 1988).

SARB includes isolates of several medically important serovars for which MLEE analysis has identified infrequently recovered ETs that are distantly related to the common and widespread ET of the serovar. $S$. infantis In 3 (division F), which is known from a single strain isolated in Senegal, differs from the globally distributed In 1 (division C) at 10 enzyme loci; $S$. paratyphi $C$ Pc 4 (division F) differs from Pc 1 and Pc 2 (division B) at 11 and 12 loci, respectively (Selander et al., 1990 b); and $S$. choleraesuis Cs 1 and Cs 11 are closely related to one another and to $S$. paratyphi $C \mathrm{Pc} 1$ and Pc 2 (division B), but Cs 6 (division C) and Cs 13 (division A) represent phylogenetically distinct lineages.

SARB also includes several examples in which different serovars are represented by closely related ETs. For example, $S$. haifa $\mathrm{Ha} 1$ and $S$. saintpaul $\mathrm{Sp} 3$, representing serovars that differ in expression of phase 1 flagellar antigenic factors (Table 1), were indistinguishable in multilocus enzyme genotype (Table 2).

Both clones of $S$. typhi (Tp 1 and $\mathrm{Tp} 2)$ that were identified by Selander et al. $(1990 \mathrm{~b})$ are represented in SARB; they differ at two enzyme loci and cluster with $S$. derby De 1 and $S$. senftenberg Sf 1 in division E.

Recent comparative studies of nucleotide sequence variation in $f l i C$, the $r f b$ gene cluster, and several metabolic and other enzyme genes among diverse strains of Salmonella have suggested that recombination of horizontally transferred DNA segments has been an especially important evolutionary factor generating allelic and multilocus genotypic diversity in genes involved in serotype determination, presumably because of an adaptive advantage of high levels of polymorphism in cell-surface structures exposed to the environment (Selander et al., 1991; Nelson \& Selander, 1992). This hypothesis is currently being tested by sequence analysis of additional genes encoding proteins of a variety of functional types. For present purposes, it has been 
sufficient to emphasize the fact that, because of recombination (and, perhaps, convergent evolution in antigenic phenotype), identity or similarity in serotype among strains of the salmonellae does not necessarily reflect close phylogenetic relationship. Estimates of evolutionary genetic relationships among strains must be based on assessment of allelic variation in large numbers of diverse chromosomal genes.

A set of SARB has been deposited in the Salmonella Genetic Stock Centre (contact Dr K. E. Sanderson, Department of Biological Sciences, University of Calgary, 200 University Drive NW, Calgary, Alberta, Canada T2N 1N4).

Research on bacterial population genetics was supported by grant AI22144 from the National Institutes of Health.

\section{References}

Barker, R. M., Kearney, G. M., Nicholson, P., Blair, A. L., PORTER, R. C. \& CRIChton, P. B. (1988). Types of Salmonella paratyphi $B$ and their phylogenetic significance. Journal of Medical Microbiology 26, 285-293.

Beltran, P., Musser, J. M., Helmuth, R., Farmer, J. J., III, Frerichs, W. M., Wachsmuth, I. K., Ferris, K., MCWhorter, A. C., Wells, J. G., Cravioto, A. \& Selander, R. K. (1988). Toward a population genetic analysis of Salmonella: genetic diversity and relationships among strains of serotypes $S$. choleraesuis, $S$. derby, S. dublin, S. enteritidis, S. heidelberg, $S$. infantis, $S$. newport, and S. typhimurium. Proceedings of the National Academy of Sciences of the United States of America 85, 7753-7757.

Beltran, P., Plock, S. A., Smith, N. H., Whittam, T. S., Old, D. C. \& SELANDER, R. K. (1991). Reference collection of strains of the Salmonella typhimurium complex from natural populations. Journal of General Microbiology 137, 601-606.

Brown, P. K., Romana, L. K. \& Reeves, P. R. (1992). Molecular analysis of the $r f b$ gene cluster of Salmonella serovar muenchen (strain M67): the genetic basis of the polymorphism between groups C2 and B. Molecular Microbiology 6, 1385-1394.

Crosa, J. H., Brenner, D. J., Ewing, W. H. \& Falkow, S. (1973). Molecular relationships among the salmonellae. Journal of Bacteriology 115, 307-315.

Duguid, J. P., Anderson, E. S., Alfredsson, G. A., Barker, R. M. \& OLD, D. C. (1975). A new biotyping scheme for Salmonella typhimurium and its phylogenetic significance. Journal of Medical Microbiology 8, 149-166.

EwING, W. H. (1986). Edwards and Ewing's Identification of Enterobacteriaceae, 4th edn. New York: Elsevier.

Herzer, P. J., Inouye, S., InOUye, M. \& Whittam, T. S. (1990). Phylogenetic distribution of branched RNA-linked multicopy singlestranded DNA among natural isolates of Escherichia coli. Journal of Bacteriology 172, 6175-6181.

LE Minor, L. (1984). Genus III Salmonella Lignières $1900,389^{\mathrm{AL}}$. In Bergey's Manual of Systematic Bacteriology, vol. 1, pp. 427-458. Edited by N. R. Krieg \& J. G. Holt. Baltimore: Williams \& Wilkins.

Le Minor, L. (1988). Typing of Salmonella species. European Journal of Clinical Microbiology and Infectious Disease 7, 214-218.

Le Minor, L. \& Popoff, M. Y. (1987). Designation of Salmonella enterica sp. nov., nom. rev., as the type and only species of the genus
Salmonella. International Journal of Systematic Bacteriology 37, 465-468.

Le Minor, L., Popoff, M. Y., Laurent, B. \& Hermant, D. (1986). Individualisation d'une septième sous-espèce de Salmonella: $S$. choleraesuis subsp. indica subsp. nov. Annales de l'Institut Pasteur/ Microbiologie 137B, 211-217.

Lee, S. J., Romana, L. K. \& Reeves, P. R. (1992). Cloning and structure of group $\mathrm{Cl} \mathrm{O}$ antigen ( $r f b$ gene cluster) from Salmonella enterica serovar montevideo. Journal of General Microbiology 138, 305-312.

Li, J., Smith, N. H., Nelson, K., Crichton, P. B., Old, D. C., Whittam, T. S. \& Selander, R. K. (1993). Evolutionary origin and radiation of the avian-adapted non-motile salmonellae. Journal of Medical Microbiology 38, 129-139.

NeI, M. (1987). Molecular Evolutionary Genetics. New York: Columbia University Press.

Nelson, K. \& Selander, R. K. (1992). Evolutionary genetics of the proline permease gene (putP) and the control region of the proline utilization operon in populations of Salmonella and Escherichia coli. Journal of Bacteriology 174, 6886-6895.

Nelson, K., Whittam, T. S. \& Selander, R. K. (1991). Nucleotide polymorphism and evolution in the glyceraldehyde-3-phosphate dehydrogenase gene (gap $A)$ in natural populations of Salmonella and Escherichia coli. Proceedings of the National Academy of Sciences of the United States of America 88, 6667--6671.

Reeves, M. W., Evins, G. M., Heiba, A. A., Plikaytis, B. D. \& FARMER, J. J., III (1989). Clonal nature of Salmonella typhi and its genetic relatedness to other salmonellae as shown by multilocus enzyme electrophoresis, and proposal of Salmonella bongori comb. nov. Journal of Clinical Microbiology 27, 313-320.

SAITOU, N. \& NEI, M. (1987). The neighbor-joining method: a new method for reconstructing phylogenetic trees. Molecular Biology and Evolution 4, 406-425.

Selander, R. K., Caugant, D. A., Ochman, H., Musser, J. M., Gilmour, M. N. \& WhitTaM, T. S. (1986). Methods of multilocus enzyme electrophoresis for bacterial population genetics and systematics. Applied and Environmental Microbiology 51, 873-884.

Selander, R. K., Beltran, P., Smith, N. H., Barker, R. M. Crichton, P. B., Old, D. C., Musser, J. M. \& Whittam, T. S. $(1990 a)$. Genetic population structure, clonal phylogeny, and pathogenicity of Salmonella paratyphi B. Infection and Immunity 58, 1891-1901.

Selander, R. K., Beltran, P., Smith, N. H., Helmuth, R., Rubin, F. A., Kopecko, D. J., Ferris, K., Tall, B. D., Cravioto, A. \& MusSER, J. M. (1990 b). Evolutionary genetic relationships of clones of Salmonella serovars that cause human typhoid and other enteric fevers. Infection and Immunity 58, 2262-2275.

Selander, R. K., Beltran, P. \& Smith, N. H. (1991). Evolutionary genetics of Salmonella. In Evolution at the Molecular Level, pp. 25-57. Edited by R. K. Selander, A. G. Clark \& T. S. Whittam. Sunderland, Massachusetts: Sinauer Associates.

Selander, R. K., Smith, N. H., Li, J., Beltran, P., Ferris, K. E. KOPECKO, D. J. \& RUBIN, F. A. (1992). Molecular evolutionary genetics of the cattle-adapted serovar Salmonella dublin. Journal of Bacteriology 174, 3587-3592.

Smith, N. H. \& Selander, R. K. (1990). Sequence invariance of the antigen-coding central region of the phase 1 flagellar filament gene (fiC) among strains of Salmonella typhimurium. Journal of Bacteriology 172, 603-609.

SMITH, N. H. \& Selander, R. K. (1991). Molecular genetic basis for complex flagellar antigen expression in a triphasic serovar of Salmonella. Proceedings of the National Academy of Sciences of the United States of America 88, 956-960.

Smith, N. H., Beltran, P. \& Selander, R. K. (1990). Recombination of Salmonella phase 1 flagellin genes generates new serovars. Journal of Bacteriology 172, 2209-2216.

Wang, L., Romana, L. K. \& Reeves, P. R. (1992). Molecular analysis of a Salmonella enterica group E1 $r f b$ gene cluster: O antigen and the genetic basis of the major polymorphism. Genetics 130, 429-443. 